\title{
On Recent Trends in Consumer Perception and Behaviour Towards Organic Food
}

\author{
K.Gunaseelaprabhu, Ramya.J
}

\begin{abstract}
Food consumption practice is changing worldwide among consumers. They have opted to go for food products which are free from synthetic chemicals, pesticides and fertilisers. The health issues and environmental hazards have been the driving forces behind the shift towards the consumption patterns. Therefore people wish to go for the agricultural products which are grown with the naturally available grains and genetically non-modified seeds which are termed as organic foods. Besides health benefits, the organic foods proves to be better for the environment too. The use of chemical fertilizers and pesticides to keep away the bugs in turn affect the humans and soil too. Hence a consumer prefers to go for quality food taking and his perception towards organic food is based on more desirable characteristics such as nutritive value and taste. The present study enables to understand the recent trends in consumer perception and behaviour towards organic food. The objective of this study is to learn about consumer perception and behaviour and to understand about the key factors that motivate the consumers to choose organic food. The study will also help to obtain knowledge about the purchase intention and attitude of the consumers. The findings of the present study would add insight to emerging organic food industry in India and worldwide and consumers interest and satisfaction towards it.
\end{abstract}

Index Terms: Organic food, Chemical Fertilisers, Consumer Attitude, Consumer Perception \& Consumer Satisfaction..

\section{INTRODUCTION}

Organic Farming is becoming increasingly popular not only in India but all over the world. Many People have started feeling a disenchant from using the agricultural produces received from chemically cultivated farms and started to make effort to buy organically cultivated food. The reasons are obviously related to their concerns for the well-being of their family members as well as health of the environment.

The good taste and nutritional value of organic food also attract the consumers. The usage of chemicals inevitably leave the residue in the produce. There are more than 130 classes of pesticides used in the course. The residues of the used pesticides enter the food via four ways: on-farm use, post-harvest pesticide, pesticides used on imported food and cancelled pesticides that persist in the environment. According to WHO reports, approximately around one

Revised Manuscript Received on July 08, 2019.

* Correspondence Author

Dr.K.Gunaseelaprabhu*, Associate Professor, Department of Management Sciences, Sri Ramakrishna College of Arts and Science, Coimbatore-641006.

Ramya.J, Research Scholar (Full time), Department of Management Sciences, Sri Ramakrishna College of Arts and Science, Coimbatore-641006. million people are taken ill every year with pesticides poisoning and 20,000 of them die due to variety of health issues and more importantly reproductive health impacts on women. Thus, the extensive use of chemicals and antibiotics in inorganic food production has compelled people to support organic farming. There is wide spread belief that organic food is significantly healthier and safer than inorganic food and consumers are willing to pay a price premium to procure it.Organic farming uses biologically natural materials and processes to cultivate food. The practice aims to protect human health and conserve the environment and natural resources for the future generations to come.

Thus, the interest in organically -produced food is on the increasing trend across the world and due to the re-adoption of conventional agricultural practices, food safety and human health concerns and environment concerns is increasing, the examining of consumer perception towards organic foods becomes a necessity. The present study revolves around the psychological processes that consumers go through in identifying the needs, search for information, evaluating the products and making a final purchase.

\section{Literature Review}

Singh and Dinesh Kumar (2007) have explained organic farming, human health and environment. The study revealed that Organic Agriculture as a viable alternative as it enlivens the soil, strengthens the natural resource base and sustains biological production at different levels there by resulting in pollution free environment, quality food and health and good fodder besides reducing risks of heart attacks, cancer and many other diseases.

Mohamed Bilal Basha and Ramesh.k (2014) have emphasized that the consumer attitude towards purchasing organic food is strongly influenced by health consciousness and environment and safety concerns. The findings of the study reveal health concern is the first motivation of organic food consumers.

Ramesh and Divya (2014) have stated that the main reasons for purchasing Organic Food products are an expectation of a healthier and environment friendly means of production in addition consumers trust in the quality of goods and price. However finally the authors explain that the main barrier to increase the market share of Organic food products is consumer information.

Chandrasekhar (2014) explains about consumers' willingness to pay high cost towards Organic food as an investment in human health. 
Knowledge and awareness about Organic products could affect Attitude and Perception about the product and ultimately the buying decisions of the Consumers.

Neha Singhal (2017) have explained about several benefits including healthiness and sustainable production. The study attempts to explain that Organic food largely lack consumer support and less market demand due to lack of knowledge, trust and information about such food products.

Objectives of the Study

- To Understand the Recent Trends in Consumer Perception and Behavior towards Organic Food.

- To know about the key factors that motivate the consumers to choose Organic Food.

- To obtain knowledge about the Purchase Intention and Attitude of the Consumers.

\section{Methodology}

In order to review the extensive literature, information were gathered from various research articles published in referred journals and also in electronic databases related to organic food market at the world and Indian scenario. Later, an extensive review of the literature was conducted in order to consider the perceptions of consumers towards organic food products. The journals provided with the creditable work of various scholars worldwide which helped to conduct the work. In addition to this, various references were cited from published articles and reports related to organic food products

The Organic Food Cultivation and Consumption

World Trends in Organic Food Consumption

Organic food market has grown and has expanded day by day and by 2010 it has been estimated that the total growth was $23 \%$. The organic food market in total was observed to be 59.1 billion U.S Dollars. Among all European countries, Italy, Germany, France, Switzerland and Austria are the leading countries in the sector of organic fruit production. The Italian and Singapore markets are also in growing trend. In addition to fruit production, there aroused the demand for many other commodities and gave opportunities to countries like India. Organic food products are greatly popular across Europe and USA.India however not a prominent consumer of organic food but plays a prominent role in production by being one among the top 10 in cultivation of organic produces. Both Developed and developing countries has raised its demand and consumption levels for organic food. The Perception of people of Malaysia on organic food production is all about the avoiding of using harmful chemicals on land. In 2015,179 countries had data on its organic cultivation.50.9\% million hectares of agricultural land were organic which included converted areas. (www.fibl.org).In the EU, Germany is a leading country in terms of organic production; followed by Italy and France. The European Union and the United States (US) are approximately at the same level of organic production, somewhere between 4 and 6 billion Euros per year, with Japan at third place. In respect of worldwide organic food consumption Denmark and Austria lead the way with 37.3 and 34 Euro per capita consumption per year. The average consumption of organics in EU and USA is approximately 16 Euro (\$15) per capita per year. The worldwide market share for organic products is between 0.5 to $3 \%$, but it is hard to determine, as some countries do not certify their products.

The Organic food retail outlets have considerably increased during the recent years and statistics show that not only specialized retailers sell organic foods but also the traditional super markets. The Whole Foods Market and Sprouts Farmers Market are widely known specialized organic retailers in US. Whole Food Market was founded in 1980 and operates more than 450 stores in US. In UK, mid 1980's Sainsbury stocked only 10 organic product lines but in contrast now it offers 1300 organic product lines and it sells $65 \%$ of organic food throughout the country now. Countries like Sweden have reported trading 90\% organic produces, Switzerland trade $75 \%$ more and Czech Republic trades $60 \%$ more than the early days. These represent an increasingly lucrative emerging category. In recent study, organic retailers in European Union expanded their sales to over 400 organic product lines.

Organic Food Sales World wide

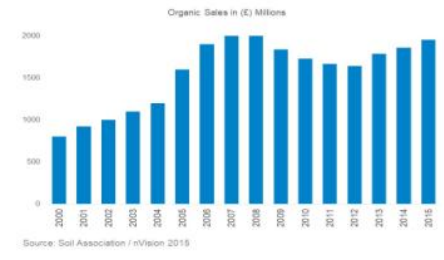

\section{Organic Food Consumption in India}

India progress in organic sector is remarkable. Its domestic market has reported growing by $25 \%$.During 1990 's the organic sector limited its exports only to tea but now India is emerging as a key player in global arena by exporting more than 300 product lines in organic category. Retailing organic products therefore represents an opportunity for conventional supermarkets to further increase their retail dominance, since organic consumer market is growing and expanding.

Consumer Perception and Behavior towards Organic Food Consumer behavior plays a major role in organic food products segment. The marketers of organic food needs to be innovative and dynamic to meet the changing purchase behavior for organic food products among the consumers. The majority of organic food consuming respondents believes that organic food products contains no pesticides, while most of the non-organic food consuming respondents believes that organic food commodities are natural products and always priced high. The main reason behind buying an organic food product is health consciousness. Though the organic food product was regarded healthy, the lack of trust on the originality of organic food product was another reason for not buying the organic food products. Hence, the firm producing and selling organic food products must find ways to create trust among the consumers to improve their purchase intentions. It is assessed 
that consumer perception towards organic food is bound around food safety, human health and environmental concern along with sensory attributes such as nutritive value, taste, freshness and appearance. Premium price continues to suppress organic food consumption. Understanding the grounds of increasing level of organic food consumption such as motivation are most critical in understanding the potential of the organic food to become a genuinely mainstream market. Consumers' perceptions regarding organic food consumption are influenced by five factors, namely food safety, price, environmental friendly, nutrition and sensory attributes. Interest in organically produced food is changing end-to-end the world. It is found that six significant factors were to influence the attitude towards organic food. They were perception towards organic food, health consciousness, and product information, value for money, accessibility and trust. Women and younger consumers showed a positive attitude towards organic food and perceived consumption of organic food to be a healthier food option. They were keen on getting product information and compared labels while selecting nutritious food. Consumers are very much aware that organic food are good for health. The consumers living in urban areas are more aware about organic food products. Consumer believes that consuming of organic food helps to reduce stress level and maintain an energetic lifestyle. It is actually convincing that many consumers are willing to pay even higher prices because it is beneficial for health. Further the literature study reveals that consumers prefer to buy organic food products because of their perception that the organic food products are healthy and safe, nutritious and environment friendly. Finally it is concluded ten factors such as labels, health, concern, environment concern, brand advertising, safety, accessibility, affordability, freshness and store location as influencing factors to buy organic food. In general though organic foods are usually offered at a higher price level than their conventional counterparts, a recent survey revealed that consumers actively try to include organic products in their diet.

\section{RESULTS}

Results of the research showed consumers showed a positive attitude towards organic food and perceived consumption of organic food to be a healthier food option. The Governments of various developed and developing nations worldwide should advance the policies to encourage organic agriculture and food safety while non-Governmental organizations should raise the awareness of consumer's health consciousness, environmental concern and food safety.

\section{CONCLUSION}

This above Research paper provides a better understanding of what moderates the consumer perception and behavior towards organic foods. The article further indicates the consumer concerns about health which is the main determinant in forming a positive attitude towards the organic food. The previous studies have also consistently proved the same. The Governments of various developed and developing nations worldwide should advance the policies to encourage organic agriculture and food safety while non-Governmental organizations should raise the awareness of consumer's health consciousness, environmental concern and food safety.

\section{REFERENCES}

1. Balaji V, Injodey JI. Organic Food Products: A Study on Perceptions of Indian Consumers. Indian Journal of Marketing. 2017, 47(1).

2. Chandrashekar HM. Consumers Perception towards Organic Products - A Study in Mysore City, International Journal of Research in Business Studies and Management. 2014; 1(1):61-66.

3. Hughner R, McDonagh S, Prothero ACJ, Shultz II Stanton J. Who are organic food consumers? A compilation and review of why people purchase organic food. Journal of consumer behavior. 2007; 6:1-17.

4. Magnusson M, Arvola A, Koivisto Hursti U, Aberg L, Sjoden P. Attitudes towards organic foods among Swedish consumers. British Food Journal. 2001; 103(3):209-26.

5. Mehra S, Ratna PA. Attitude and behavior of consumers towards organic food: an exploratory study in India. International Journal of Business Excellence. 2014; 7(6):677-696.

6. Mohamed Bilal Basha, Ramesh K. Consumer Attitude towards Organic Food in Trichy - South India 2014; 5(5):1-10.

7. Mukul AZA, Afrin S, Hassan M. Factor's affecting consumers' perceptions about organic food and their prevalence in Bangladeshi organic preference. Journal of Business and Management Sciences. 2013; $1: 112-118$

8. Shafie FA, Rennie D. Consumer Perceptions towards Organic Food. Procedia Social and Behavioral Science. 2012; 49:360-367.

9. Sharma G, Dewan R, Bali S. Factors Influencing Consumer Buying Behavior \& Awareness towards Organic Food: A Study of Chandigarh \& Panchkula Consumers. International Journal of Science and Research. 2014; 5(2):689-696

10. Singh. Y.V., and Dinesh Kumar., (2007),'Organic Farming vis-a- vis Human Health and Environment". Kurukshetra, Vol. 55(4), The Ministry of Rural Development, pp:3-7

11. Singhal, Neha, A Study of Consumer Behaviour towards Organic Food and the Moderating Effects of Health Consciousness (2017)

12. Pandurangarao D, Chiranjeevi K, Rao DS. Factors Affecting Consumers to Buy Organic Food Products in Hyderabad and Secuderabad. International Journal of Business and Management Invention. 6(3), 24-30.

13. Ramesh SV, Divya M. A Study on Consumers'Awareness Attitude and Satisfaction towards Select

14. Organic Food Products with Reference to Coimbatore,International Journal of Interdisciplinary and Multidisciplinary Studies, (IJIMS). $2015 ; 2(4): 81-84$

15. Richter, T., Schmid, O., Damary, P., van den Berge, P., Meier, U. and Halpin,.(2000).International study of retail chains with regard to their activities in the marketing of organic products', in the Proceedings of the IFOAM 2000 Conference: The World Grows Organic, Basel Switzerland, 28-30 August.

16. Richter, T. (2004) 'Marketing organic products via European retail $\begin{array}{lll}\text { chains',presentation at } & \text { Biofach }\end{array}$ http://www.orgprints.org/1893/01/richter-2004-biofach.retail.pdf

17. Wier M, Andersen LM, Millock K. Consumer demand for organic foods attitudes, values and purchasing", paper presented at SOM Workshop, Environment, Information and Consumer, Frederiksdal, April, 2003.

18. Yadav AK. Organic Agriculture, Concept, Scenario, Principals and Practices. Director National Centre of Organic Farming, Ghaziabad National Centre of Organic Farming Department of Agriculture and Cooperation, Ministry of Agriculture, Government of India, Uttar Pradesh, 2010

\section{AUTHORS PROFILE}

Dr.K.Gunaseelaprabhu Associate Professor, Department of Management Sciences, Sri Ramakrishna College of Arts and Science, Coimbatore-641006.

Ramya.J Research Scholar (Full time), Department of Management Sciences, Sri Ramakrishna College of Arts and Science, Coimbatore-641006. 